\title{
Measurement of Glycosylated Haemoglobins and Glycosylated Plasma Proteins in Maternal and Cord Blood Using an Affinity Chromatography Method
}

\author{
P. M.Hall ${ }^{1}$, G. M. Cawdell ${ }^{2,}$, J.G. H. Cook ${ }^{1}$ and B. J. Gould ${ }^{3}$ \\ Departments of ${ }^{1}$ Biochemistry and ${ }^{2}$ Obstetrics and Gynaecology, Royal Sussex County Hospital, Brighton, East Sussex and \\ ${ }^{3}$ Biochemistry Department, University of Surrey, Guildford, Surrey, UK
}

Summary. We have used a simple affinity chromatography method to measure total glycosylated haemoglobins and glycosylated plasma proteins in maternal and cord blood at 50 normal deliveries. The affinity method gives equal weighting to glycosylated haemoglobins including haemoglobin $F$ in cord blood. The mean values for glycosylated haemoglobins in maternal blood $(6.49 \pm 1.2 \%)$ were significantly higher than those in cord blood $(3.85 \pm 1.0 \% ; p<0.001)$. The difference with glycosylated plasma proteins was less marked (maternal blood $5.61 \pm 0.9 \%$ and cord blood $4.75 \pm 0.6 \% ; p<0.001$ ). A contributory factor to these differences was the decrease in glucose concentration from $4.53 \pm 0.99 \mathrm{mmol} / 1$ in maternal blood to $3.59 \pm 0.8 \mathrm{mmol} / 1$ in cord blood. The results obtained at the birth of six children to diabetic mothers showed the same trends although the mean values for glycosylated haemoglobins (maternal blood $9.27 \pm 2.3 \%$, cord blood $4.21 \pm 0.9 \%$ ), glycosylated plasma proteins (maternal blood $7.44 \pm 1.6 \%$, cord blood $5.45 \pm 1.7 \%$ ) and glucose (maternal blood $10.22 \pm 7.3 \mathrm{mmol} / 1$, cord blood $5.18 \pm 3.4 \mathrm{mmol} / \mathrm{l}$ ) were higher in all samples than for the deliveries to non-diabetic mothers.

Key words: Affinity chromatography, cord blood, diabetes, diabetic pregnancy, glycosylated fetal haemoglobin, glycosylated fetal plasma proteins, glycosylated haemoglobins, glycosylated plasma proteins.
The measurement of glycosylated haemoglobins (Gly$\mathrm{Hb}$ ) is well recognized as a retrospective assessment of glycaemic control in diabetic patients [1]. As a clinical tool, these haemoglobins are most useful in labile diabetes such as occurs in pregnancy where their concentration correlates with mean maternal glycaemia [2]. Despite improvements in the control of maternal diabetes during pregnancy, macrosomia, neonatal morbidity and congenital malformations are still frequent in centres with low perinatal mortality [3]. Several methods have been used to determine glycosylated haemoglobins during pregnancy. These include ion-exchange chromatography [3-9], high pressure liquid chromatography [10], and radioimmunoassay of $\mathrm{HbA}_{1 \mathrm{c}}$ [11].

It is also possible to determine Gly- $\mathrm{Hb}$ in cord blood and this might be used as an index of fetal exposure to glucose during the last few weeks of pregnancy [12]. The measurement of glycosylated haemoglobin $\mathrm{F}$ has been carried out using ion-exchange chromatography $[13,14]$ and isoelectric focusing $[12,15]$ but both techniques probably measure the total of glycosylated

\footnotetext{
* Present address: Department of Obstetrics and Gynaecology, King's College Hospital, London. UK
}

haemoglobin $\mathrm{F}$ and acetylated haemoglobin $\mathrm{F}[12,14]$. $\mathrm{HbA}_{1 \mathrm{c}}$ has also been measured in cord blood by radioimmunoassay [16] and may be useful in the future for the determination of gestational age in the third trimester.

A simple, sensitive affinity chromatography technique which can be used for the measurement of glycosylated haemoglobins $[17,18]$ is now available commercially. It is rapid and suitable for use in a routine clinical laboratory for monitoring all diabetic patients including those who are pregnant. In this paper we report the ranges for normal pregnancies at term, and show that this single technique, with minor modification, can be used to determine both glycosylated haemoglobins and glycosylated plasma proteins in adult and fetal blood.

\section{Subjects and Methods}

\section{Subjects}

Fifty live births to non-diabetic women were monitored; 19 of the mothers were primigravidae. Most births were normal vaginal deliveries. but there were four forcens deliveries and three bv Caesarean sec- 


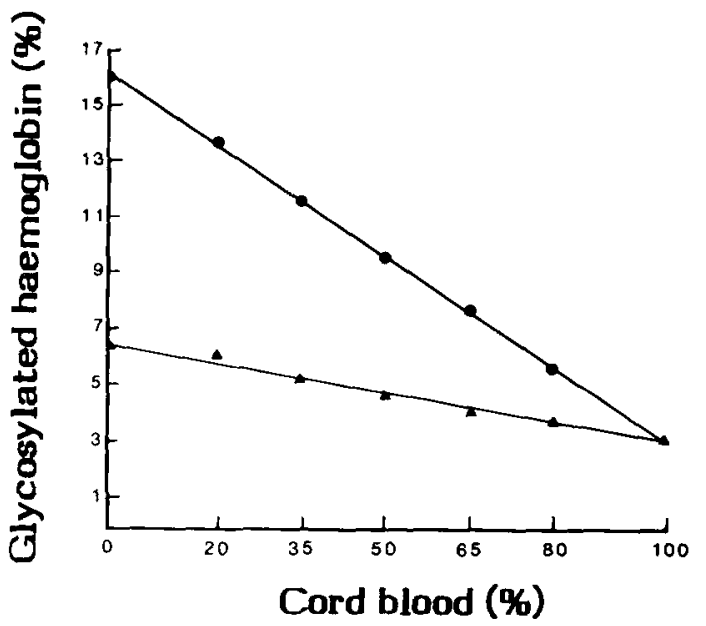

Fig. 1. Effect on the value of glycosylated haemoglobin of mixing cord blood with non-diabetic maternal blood and blood from a diabetic. Increasing amounts of cord blood were added to non-diabetic maternal blood $(\Delta)$ and diabetic blood $(\bullet)$ in the proportions indicated. The glycosylated haemoglobins were then measured by affinity chromatography

tion. Gestational age of the fetus was based on the mothers menstrual history and ultrasound examinations. Maternal and cord bloods for analysis were taken immediately after birth. For the glucose estimation, the sample was preserved using fluoride oxalate; a further sample of each was taken into a standard lithium heparin tube to prevent coagulation. The mean age of the mothers was 28 years (range 19 to 42 years). The mean \pm SD birth weight was $3.417 \pm 0.518 \mathrm{~kg}$ with the observed range being $2.280-4.360 \mathrm{~kg}$. All the births were within 2.5 weeks of the predicted date of delivery. Six live births to insulin-dependent diabetic patients were also monitored. Maternal and cord bloods for analysis were taken immediately after birth, and were treated in an identical manner to the samples from normal subjects.

\section{Measurement of Blood Glucose}

Whole blood glucose was measured using the Yellow Springs Glucose Analyser Model 23AM (Yellow Springs Instruments, Yellow Springs, Ohio, USA). This was usually carried out within 30 min of sampling, but when this was not possible, the sample was stored at $4^{\circ} \mathrm{C}$.

\section{Measurement of Glycosylated Haemoglobins}

Glycosylated haemoglobins were measured by the previously reported affinity chromatography technique [18]. This method uses an $\mathrm{m}$-aminophenylboronate agarose gel, Glycogel B (Pierce \& Warriner, Chester, UK) for the separation of glycosylated from non-glycosylated material. The $\mathrm{pH}$ of the buffers used for the chromatography was 8.3.

For each sample, plasma was separated from the erythrocytes by centrifugation at $1200 \mathrm{~g}$ for $10 \mathrm{~min}$. Then $100 \mu \mathrm{l}$ of packed red blood cells were diluted with $2 \mathrm{ml}$ of deionised water and incubated at $37^{\circ} \mathrm{C}$ for $5 \mathrm{~h}$ to remove labile material [19]. The stable sample was then stored at $4{ }^{\circ} \mathrm{C}$ until analysis, in most cases up to a maximum of $48 \mathrm{~h}$.

\section{Measurement of Glycosylated Plasma Proteins}

Plasma was diluted 1 in 20 with deionised water and incubated at $37^{\circ} \mathrm{C}$ for $5 \mathrm{~h}$. Diluted plasma $(150 \mu \mathrm{l})$ was added to a $1 \mathrm{ml}$ column of Glycogel B. The unbound material was removed with $8 \mathrm{ml}$ of wash buffer and the bound fraction eluted with $3 \mathrm{ml}$ of elution buffer. Both buffers were as used previously [18], except that they were adjusted to
$\mathrm{pH}$ 8.9. The protein in both the unbound fraction (diluted to $24 \mathrm{ml}$ ) and the bound fraction was measured at $595 \mathrm{~nm} 30 \mathrm{~min}$ after mixing with an equal volume of an acidified Bradford reagent [19]. This reagent was prepared from the Biorad protein assay reagent (Bio-Rad Laboratories, Watford, Hertfordshire, UK) diluted with water and glacial acetic acid in the ratio $4: 5: 1$. This method is modified from that recommended by the suppliers of Glycogel B to avoid overloading the gel columns with protein [20].

\section{Effect of Fetal Haemoglobin on Affinity Chromatography Method}

Packed red blood cells obtained from cord blood were mixed in different proportions with either the appropriate maternal blood or with erythrocytes from a diabetic patient. The samples used contained $100 \%, 80 \%, 65 \%, 50 \%, 35 \%, 20 \%$ and $0 \%$ of cord blood in each case. Each sample was mixed and a $100 \mu \mathrm{l}$ aliquot was diluted in $2 \mathrm{ml}$ of deionized water and incubated at $37^{\circ} \mathrm{C}$ for $5 \mathrm{~h}$ to remove any labile material, and then analysed in triplicate using the method outlined for glycosylated haemoglobins.

\section{Effect of Fetal Haemoglobin on Agar Gel Electrophoretic Method}

Erythrocytes from cord and maternal blood were diluted 1 in 20 with isotonic saline $(0.15 \mathrm{mmol} / 1 \mathrm{NaCl})$ and incubated at $37^{\circ} \mathrm{C}$ for $5 \mathrm{~h}$. The erythrocytes were then recovered and the assessment of glycosylated haemoglobins in the haemolysed cells was determined by both the affinity method and the standard procedure for agar gel electrophoresis marketed by Corning (Corning Medical, Halstead, Essex, UK).

\section{Statistical Analysis}

Statistical comparisons were performed by Student's t-test.

\section{Results}

\section{Effect of Fetal Haemoglobin on Methods for Measuring Glycosylated Haemoglobins}

Figure 1 shows that when cord blood was mixed with either haemoglobin from a normal mother or haemoglobin from a diabetic mother in different proportions between $0 \%$ and $100 \%$, straight lines were obtained. This indicates that the haemoglobin $F$ and the normal adult haemoglobin are given equal weighting by the affinity method. However, when samples of cord blood were tested by the agar gel electrophoretic method there was gross interference by haemoglobin $\mathrm{F}$ (Table 1). The mean value for the maternal samples using the affinity method was $5.8 \%$, and for the cord samples it was $4.0 \%$. The corresponding values obtained by the agar gel electrophoretic method were $6.7 \%$ and $81.5 \%$, respectively.

Values of Glycosylated Haemoglobins, Glycosylated Plasma Proteins and Glucose in Maternal and Cord Blood of Normal Pregnancies

Table 2 summarizes the results of glycosylated haemoglobins, glycosylated plasma proteins and glucose mea- 
Table 1. Glycosylated haemoglobins in cord and maternal samples non-diabetic (A-H) and diabetic (I and J) mothers

\begin{tabular}{|c|c|c|c|c|c|c|c|c|c|c|}
\hline & \multicolumn{10}{|l|}{ Births } \\
\hline \multicolumn{11}{|l|}{ Maternal blood } \\
\hline Agar gel electrophoresis $(\%)$ & 6.0 & 6.2 & 6.6 & 5.4 & 8.3 & 5.7 & 6.2 & 7.0 & 8.0 & 8.0 \\
\hline \multicolumn{11}{|l|}{ Cord blood } \\
\hline
\end{tabular}

The Affinity Chromatography Method measures glycosylated haemoglobins (\%) and agar gel electrophoresis gives the percentage in the fast fraction

Table 2. Values for glycosylated haemoglobins, glycosylated plasma proteins and glucose in maternal and cord blood of non-diabetic mothers at delivery

\begin{tabular}{lccc}
\hline & $\begin{array}{l}\text { Glycosylated } \\
\text { haemoglobins } \\
(\%)\end{array}$ & $\begin{array}{l}\text { Glycosylated } \\
\text { plasma proteins } \\
(\%)\end{array}$ & $\begin{array}{l}\text { Glucose } \\
(\mathrm{mmol} / 1)\end{array}$ \\
\hline $\begin{array}{l}\text { Maternal blood } \\
(n=50)\end{array}$ & $6.49 \pm 1.22$ & $5.61 \pm 0.93$ & $4.53 \pm 0.99$ \\
$\begin{array}{l}\text { Cord blood } \\
(n=50)\end{array}$ & $3.33-9.13)$ & $(3.47-7.79)$ & $(2.4-8.7)$ \\
\hline
\end{tabular}

Results are expressed as mean $\pm \mathrm{SD}$; observed range in parentheses

Table 3. Values for glycosylated haemoglobins, glycosylated plasma proteins and glucose in maternal and cord blood of six diabetic mothers at delivery

\begin{tabular}{|c|c|c|c|c|}
\hline Patient & & $\begin{array}{l}\text { Glycosylated } \\
\text { haemoglobins } \\
(\%)\end{array}$ & $\begin{array}{l}\text { Glycosylated } \\
\text { plasma } \\
\text { proteins }(\%)\end{array}$ & $\begin{array}{l}\text { Blood } \\
\text { glucose } \\
(\mathrm{mmol} / 1)\end{array}$ \\
\hline 1 & $\begin{array}{l}\text { Maternal } \\
\text { Cord }\end{array}$ & $\begin{array}{l}8.56 \\
3.33\end{array}$ & $\begin{array}{l}7.66 \\
4.63\end{array}$ & $\begin{array}{l}5.0 \\
2.6\end{array}$ \\
\hline 2 & $\begin{array}{l}\text { Maternal } \\
\text { Cord }\end{array}$ & $\begin{array}{r}12.21 \\
5.25\end{array}$ & $\begin{array}{l}8.99 \\
6.76\end{array}$ & $\begin{array}{l}9.4 \\
1.4\end{array}$ \\
\hline 3 & $\begin{array}{l}\text { Maternal } \\
\text { Cord }\end{array}$ & $\begin{array}{l}6.43 \\
4.76\end{array}$ & $\begin{array}{l}7.76 \\
5.32\end{array}$ & $\begin{array}{l}24.7 \\
11.3\end{array}$ \\
\hline 4 & $\begin{array}{l}\text { Maternal } \\
\text { Cord }\end{array}$ & $\begin{array}{r}10.30 \\
4.59\end{array}$ & $\begin{array}{l}8.13 \\
5.47\end{array}$ & $\begin{array}{l}8.2 \\
5.8\end{array}$ \\
\hline 5 & $\begin{array}{l}\text { Maternal } \\
\text { Cord }\end{array}$ & $\begin{array}{l}7.02 \\
2.85\end{array}$ & $\begin{array}{l}4.35 \\
2.81\end{array}$ & $\begin{array}{l}6.4 \\
5.0\end{array}$ \\
\hline 6 & $\begin{array}{l}\text { Maternal } \\
\text { Cord }\end{array}$ & $\begin{array}{r}11.12 \\
4.47\end{array}$ & $\begin{array}{l}7.75 \\
7.70\end{array}$ & $\begin{array}{l}7.6 \\
5.0\end{array}$ \\
\hline $\begin{array}{l}\text { Mean } \pm \\
\text { Mean } \pm\end{array}$ & $\begin{array}{l}\text { SD, Maternal } \\
\text { SD, Cord }\end{array}$ & $\begin{array}{l}9.27 \pm 2.31 \\
4.21 \pm 0.92\end{array}$ & $\begin{array}{l}7.44 \pm 1.59 \\
5.45 \pm 1.70\end{array}$ & $\begin{array}{r}10.22 \pm 7.25 \\
5.18 \pm 3.43\end{array}$ \\
\hline
\end{tabular}

surements for the cord and maternal blood samples of 50 live births of healthy infants to 50 normal mothers. The mean value for each parameter was significantly lower in the cord sample $(p<0.001)$, and therefore the infant, than in the mother's blood. There was overlap between the observed ranges for each of these three parameters (Table 2), but also a marked trend towards lower values in the cord samples for each infant when compared with its mother. The glycosylated haemo- globin values in the cord samples were all lower than the corresponding maternal value, but five cord samples had higher glycosylated plasma proteins. In three cases, the glucose concentration in the cord blood was higher than that in the mother, and in one of these, the glycosylated plasma proteins were also raised.

The mean percentage glycosylated plasma protein values for the maternal population were significantly lower than those for glycosylated haemoglobins $(p<$ 0.001 ). In contrast, in cord blood the glycosylated plasma proteins were higher than the glycosylated haemoglobin values $(p<0.001)$.

\section{Results from Diabetic Pregnancies}

The values for glycosylated haemoglobins, glycosylated plasma proteins and blood glucose in maternal and cord blood samples from six diabetic mothers are shown in Table 3. As observed with the non-diabetic mothers, the results from cord blood are lower than those from maternal blood samples. Comparison of Tables 2 and 3 shows a higher mean value for each measurement in samples from diabetic subjects. Since only six results are at present available no further statistical analysis has been done.

\section{Discussion}

The affinity chromatography method provides a simple, sensitive and rapid method for measurement of both glycosylated haemoglobins and glycosylated plasma proteins. The separation technique depends on the affinity of the stationary phase (Glycogel B) for the carbohydrate moiety of either glycosylated haemoglobins or glycosylated plasma proteins. For this reason it should be independent of the haemoglobin variant and should measure the sum of the glycosylated haemoglobins including glycosylated haemoglobin $\mathrm{F}$ and haemoglobin A. Figure 1 clearly illustrates that fetal haemoglobin does not interfere with the affinity method. Other methods utilising small changes in charge to separate glycosylated and non-glycosylated material may be affect- 
ed by the type of haemoglobin if this carries a different charge. The resulting interference is clearly shown by the results of the agar gel electrophoresis method where the fetal haemoglobin runs with the fast fraction of $\mathrm{HbA}_{1}$.

Glycosylated haemoglobins in cord blood have been measured in several ways with results which depend on the degree of separation and the component measured. The resulting literature is confusing and apparently inconsistent. Using isoelectric focusing, results for non-diabetic mothers have been reported by two groups as 7.8.1.5\% [12] and $6.12 \pm 1.64 \%$ [15]. These values were claimed to represent the sum of glycosylated haemoglobin $\mathrm{F}, \mathrm{HbA}_{1 \mathrm{c}}$ and acetylated haemoglobin F. However, Schwartz et al. [13], using a combination of isoelectric focusing and ion-exchange chromatography, separated glycosylated haemoglobin $F(2.7 \pm 0.5 \%)$ and acetylated haemoglobin $F(14.6 \pm$ $4.8 \%$ ), which together represent more than twice the values mentioned above. With two different ion-exchange methods, Fadel et al. [14] reported the separation of two fractions; $\mathrm{HbA}_{1}(2.1 \pm 0.5 \%)$ and what they considered to be glycosylated haemoglobin $F(14.4 \pm 1.9 \%)$. The latter is more than five times greater than the percentage of glycosylated haemoglobin F reported by Schwartz et al. [13]. With all these methods, measurement of one or more glycosylated fractions is rendered inaccurate because of contamination with non-glycosylated haemoglobin. Radioimmunoassay has been used for the specific measurement of $\mathrm{HbA}_{1 \mathrm{c}}$ in cord blood and a value of $1.1 \pm 0.3 \%$ was obtained for the babies of non-diabetic mothers [16]. The price of specificity in this case has been the loss of detection of a significant amount of glycosylated haemoglobin. The affinity method used for this work provides a means of isolating and measuring all glucose bound fractions of whatever haemoglobin species [18], the results $(3.85 \pm 1.01 \%)$ being understandably between the specific value for $\mathrm{HbA}_{1 \mathrm{c}}$ and the values obtained by isoelectric focusing which include acetylated haemoglobin F.

Prevous studies have shown that $\mathrm{Gly}-\mathrm{Hb}$ is either unchanged $[3,6,9]$ or slightly decreased [22] during normal pregnancy. This study is in agreement with these findings, since the value obtained for maternal glycosylated haemoglobins was $6.49 \pm 1.2 \%$ compared with the normal value of $7.31 \pm 0.9 \%$ [18]. This significant decrease $(p<0.001)$ may be caused by the increase in red cell volume and decrease in fasting plasma glucose concentration that occurs during normal pregnancy [22]. Measurement of maternal glycosylated plasma proteins at term has not been reported previously. In this study we have found, not surprisingly, that it follows a similar pattern to the glycosylated haemoglobins but with a slightly smaller but significant decrease between the normal value $(6.29 \pm 1.9 \% ; p<0.02)$ (unpublished results) and that for pregnant women at delivery (5.61. $0.9 \%$ ). This is consistent with the decrease in plasma glucose concentration. Although the concentration of plasma proteins also decreases during pregnancy [23] the decrease is very small.

It is also interesting that there is an inverse ratio between the percentage of glycosylated plasma proteins and glycosylated haemoglobins in maternal and cord blood. In cord blood, the percentage of glycosylated plasma proteins is greater than Gly- $\mathrm{Hb}$, and in maternal blood the opposite is true. In maternal blood, the concentration of plasma proteins decreases during the last stages of pregnancy due to increased body fluids [23]. This, combined with the decrease in glucose and the fact that glycosylated plasma proteins reflect a shorter time period than glycosylated haemoglobins [24], probably explains the observations. In cord blood, however, there is an increased concentration of haemoglobin compared with the mother's blood which probably alters the balance so that the concentration of glycosylated plasma protein is greater than that of glycosylated haemoglobins in cord blood.

Only a few previous studies have attempted to measure glycosylated haemoglobins in both maternal and cord blood. One group using ion exchange chromatography [15] obtained a value for $\mathrm{HbA}_{1}$ in maternal blood of $6.4 \pm 0.7 \%$ and in cord blood of $12.4 \pm 3.6 \%$. However, two different chromatography procedures were used to determine these values. Using radioimmunoassay it was found that the maternal $\mathrm{HbA}_{1 \mathrm{c}}$ values were $3.96 \pm 0.7 \%$ compared with $4.56 \pm 1.8 \%$ in cord blood expressed as a percentage of haemoglobin A [16]. Another study, this time using isoelectric focusing [12], quotes maternal $\mathrm{HbA}_{1 \mathrm{c}}$ as $7.8 \pm 1.9 \%$ and glycosylated haemoglobin $\mathrm{F}$, which probably includes $\mathrm{HbA}_{1 \mathrm{c}}$ and acetylated haemoglobin $\mathrm{F}$, as $7.8 \pm 1.5 \%$.

Contrary to the findings outlined above, Sosenko et a1. [25], using a colorimetric method, found a significantly lower value (by $26 \%$ ) for Gly-Hb in cord blood compared to maternal blood. The significant decrease reported here from $6.49 \pm 1.2 \%$ for maternal blood, to $3.85 \pm 1.0 \%$ for cord blood, is in general agreement with their findings. This decrease is also consistent with the lower blood glucose in cord blood. The results for normal births show a consistent trend of lower glucose, glycosylated haemoglobins and glycosylated plasma proteins in the fetus when compared with the corresponding maternal blood. A similar trend is apparent from the preliminary data for diabetic pregnancies. It has been shown in studies in vitro that fetal haemoglobin becomes glycosylated at the same rate and to the same extent as adult haemoglobin [15]. It seems likely therefore that these lower values in the fetal blood reflect the rapid utilisation of glucose by the fetus [26].

The affinity method can offer two measurements for any patient at birth, glycosylated haemoglobins and glycosylated plasma proteins. Each of these may be useful to the clinician since they reflect different time periods of glycaemic control in pregnancy, which is a rapidly changing situation both metabolically and physiologically. Glycosylated haemoglobins reflect the glucose 
history over the previous 6-8 weeks, whereas glycosylated plasma proteins have a much shorter half-life and can provide information over a shorter time scale [24]. We are at present investigating the predictive capabilities of these measurements in relation to the complications associated with diabetic pregnancy.

Acknowledgements. We would like to thank the consultant obstetricians, R. J. Beard, J. Bostock, B. Measday and H.A.H. Melville, of the Royal Sussex County Hospital, for permission to use samples from their patients in this study. We would also like to acknowledge the staff of the labour ward for their help and skill in the collection of all the necessary samples.

\section{References}

1. Goldstein DE, Parker KM, England JD, England JE, Wiedmeyer H-M, Rawlings SS, Hess R, Little RR, Simonds JF, Breyfogle RP (1982) Clinical application of glycosylated hemoglobin measurements. Diabetes 31 (Suppl 3): 70-78

2. Jovanovic L, Peterson CM (1981) The clinical utility of glycosylated hemoglobin. Am J Med 70: 331-338

3. Ylinen K, Hekali R, Teramo K (1981) Haemoglobin $A_{1 c}$ during pregnancy of insulin-dependent diabetics and healthy controls. $\mathrm{J}$ Obstet Gynaecol 1:223-228

4. Steel JM, Thomson P, Johnstone F, Smith AF (1981) Glycosylated haemoglobin concentrations in mothers of large babies. Br Med J 282: $1357-1358$

5. Schwartz HC, King KC, Schwartz AL, Edmunds D, Schwartz R (1976) Effects of pregnancy on hemoglobin $A_{1 c}$ in normal, gestational diabetic, and diabetic women. Diabetes 25: 1118-1122.

6. Leslie RDG, Pyke DA, John PN, White JM (1978) Haemoglobin $A_{1}$ in diabetic pregnancy. Lancet 2: 958-959

7. Widness JA, Schwartz HC, Thompson D, Kahn CB, Oh W, Schwartz R (1978) Haemoglobin $A_{1 c}$ (Glycohaemoglobin) in diabetic pregnancy: an indicator of glucose control and fetal size. Br J Obstet Gynaecol 85: 812-817

8. O'Shaughnessy R, Russ J, Zuspan FP (1979) Glycosylated hemoglobins and diabetes mellitus in pregnancy. Am J Obstet Gynaecol 135: $783-790$

9. Kjaergaard J-J, Ditzel $\mathbf{J}$ (1979) Hemoglobin $\mathbf{A}_{1 \mathrm{c}}$ as an index of long-term blood glucose regulation in diabetic pregnancy. Diabetes 28: 694-696

10. Miller E, Hare JW, Cloherty JP, Dunn PJ, Gleason RE, Soeldner JS, Kitzmiller JL (1981) Elevated maternal hemoglobin $A_{1 c}$ in early pregnancy and major congenital anomalies in infants of diabetic mothers. New Engl J Med 304: 1331-1334

11. Jovanovic L, Peterson CM, Saxena BB, Dawood MY, Saudek CD (1980) Feasibility of maintaining normal glucose profiles in insulin-dependent pregnant diabetic women. Am J Med 68: 105-112
12. Poon P, Turner RC (1981) Glycosylated fetal haemoglobin. (Short report) Br Med J 283: 469

13. Schwartz HC, Widness J, Thompson D, Tsuboi KK, Oh W, Schwartz R (1980) Glycosylation and acetylation of hemoglobin in infants of normal and diabetic mothers. Biol Neonate 38:71-75

14. Fadel HE, Reynolds A, Stallings M, Abraham EC (1981) Minor (glycosylated) hemoglobins in cord blood of infants of normal and diabetic mothers. Am J Obstet Gynecol 139: 397-402

15. FitzGerald MD, Cauchi MN (1980) Determination of glycosylated hemoglobins in neonatal blood by isoelectric focusing. Am $\mathbf{J}$ Hematology 9: 311-317

16. Peterson CM, Kalan G, Jovanovic L, Jovanovic R (1979) Use of the minor hemoglobin ratio for the determination of gestational age. Am J Obstet Gynecol 135: 85-88

17. Mallia AK, Hermanson GT, Krohn RI, Fujimoto EK, Smith PK (1981) Preparation and use of a boronic acid affinity support for the separation and quantitation of glycosylated hemoglobins. Anal Lett 14: 649-661

18. Hall PM, Cook JGH, Gould BJ (1983) An inexpensive, rapid and precise affinity chromatography method for the measurement of glycosylated haemoglobins. Ann Clin Biochem 20: 121-135

19. Bradford M (1976) A rapid and sensitive method for the quantitation of microgram quantities of protein utilizing the principle of protein-dye binding. Anal Biochem 72: 248-254

20. Gould BJ, Hall PM, Cook JGH (1983) A sensitive method for the measurement of glycosylated plasma proteins using affinity chromatography. Ann Clin Biochem (in press)

21. Gould BJ, Hall PM, Cook JGH (1982) Measurement of glycosylated haemoglobins using an affinity chromatography method. Clin Chim Acta 125: 41-48

22. Lind T, Cheyne GA (1979) Effect of normal pregnancy upon the glycosylated haemoglobins. Br J Obstet Gynaecol 86: 210-213

23. Lind T (1980) Clinical chemistry of pregnancy. Adv Clin Chem 21 : $1-24$

24. Kennedy AL, Merimee TJ (1981) Glycosylated serum protein and hemoglobin $\mathrm{A}_{1}$ levels to measure control of glycemia. Ann Intern Med 95: 56-58

25. Sosenko JM, Kitzmiller JL, Fluckiger R, Loo SWH, Younger DM, Gabbay KH (1982) Umbilical cord glycosylated hemoglobin in infants of diabetic mothers: relationships to neonatal hypoglycemia, macrosomia, and cord serum C-peptide. Diabetes Care $5: 566-570$.

26. Holmberg NG, Kaplan B, Karvonen MJ, Lind J, Malm M (1956) Permeability of human placenta to glucose, fructose and xylose. Acta Phys Scandinav 36: 291-299.

Received: 28 January 1983

and in revised form: 9 May 1983

Dr. B.J.Gould

Department of Biochemistry

University of Surrey

Guildford

Surrey, UK 